\title{
Hemicellulose from cane bagasse as assessed by OLIMP MALDI-TOF/MS
}

\author{
Francis Lopes ${ }^{1 *}$, Márcio Barbosa², Marcelo Loureiro² \\ From 5th Congress of the Brazilian Biotechnology Society (SBBIOTEC) \\ Florianópolis, Brazil. 10-14 November 2013
}

Hemicelluloses are abundant polysaccharides in the plant cell walls. They tether the celulose microfibrils and participate in the control of the cell expansion together with expansins (Cosgrove, 1998) [1]. The hemicellulose may present a variety of decorating side chains, including feruloyl and acetyl substituents. The ferulic acid may be esterified to the hemicellulose and crosslinked to lignin, tethering lignin and hemicellulose to each other, increasing both hydrophobicity and recalcitrance to enzymatic digestions.

The establishment of easy accession methods to investigate the structure of the complex lignin-carbohydrate (CLC) speed up the investigation of naturally occurring or genetically introduced biomass features. The oligosaccharide mass profiling (OLIMP) consists in the cell wall digestion with specific fungal enzymes followed by the assessment of the oligosaccharides released by MALDITOF/MS (Wang et al., 1999). It is simple, informative and fast, allowing for depicting the closer native structure of polymers in muro. This work aimed to assess the hemicellulose structures occurring in bagasse of different varieties of canes by OLIMP MALDI-TOF/MS.

The oligo structures were investigated in two cell wall fractions. Cell wall residue from bagasse (BCWR) consisted in the trituration of bagasse with liquid $\mathrm{N}_{2}$ followed by sequential extractions in $80 \%$ ethanol and chloroform:methanol $(1: 1 \mathrm{v} / \mathrm{v})$. The alkali extracted hemicellulose $(\mathrm{AEH})$ came from serial alkali extraction of extractive free bagasse powder in $0.1 \mathrm{M}, 1.0 \mathrm{M}$ and 4.0M NAOH. The oligo structures were released upon digestion of BCWR or AEH with Pentopan Mono BG ${ }^{\circledR}$ or Driselase (Sigma) in $0,1 \mathrm{M}$ sodium acetate buffer, $\mathrm{pH}$ 5,6 ; at $37^{\circ} \mathrm{C}$ or $42^{\circ} \mathrm{C}$ overnight, respectively. The supernatant of the digestions were co-crystalized with $20 \mathrm{mg} /$ $\mathrm{ml}$ dihydroxybenzoic acid, prepared in $70 \%$ acetonitrile/
$0,1 \%$ trifluoroacetic acid. The peaks were collected in a Brucker Daltonics equipment and analyzed with the Flex Analysis 3.0 software.

Oligosaccharides with $\mathrm{m} / \mathrm{z} 701$ and 833 predominated the spectra from $A E H / P e n t o p a n$ Mono $B G^{\mathbb{B}}$ for all varieties of sugarcane studied. The peak of $\mathrm{m} / \mathrm{z} 701$ was confirmed to be a xylopentaose (Xyl5) in MS2 mode. The peak of $\mathrm{m} / \mathrm{z}$ 833,3 may represent a hexa-oligosaccharide (Sorensen et al., 2007) [2].

$\mathrm{BCWR} /$ Pentopan Mono $\mathrm{BG}^{\circledR}$ allowed for the detection of many feruloylated oligosaccharides. In addition, the analysis of BCWR/Driselase allowed for the detection of arabino-xylo, feruloyl-arabino-xylo and acetylated feruloyl-arabino-xylo oligosaccharides. In this experimental, the oligosaccharide of $\mathrm{m} / \mathrm{z} 745,2$ was abundant and possibly represents a feruloylated tetra-oligosaccharide. The RB867515 and Saccharum sinensis BCWR/Driselase digestions exhibited abundance of the oligo structure with $\mathrm{m} / \mathrm{z}$ 613, which may correspond to a feruloylated trisaccharide (Xyl2AraFerA). Acetyl substitutions (increases of $42 \mathrm{Da}$ ) upon the oligo structures of $\mathrm{m} / \mathrm{z}$ 613,745 and 2507,8 may have rendered the $\mathrm{m} / \mathrm{z}$ shifts of 655,787 and 2549,9 detected.

The xylopentaose (Xyl5) predominated the oligosaccharide profiles for AEH digested with Pentopan Mono $B G^{\circledR}$ for all varieties of sugarcane studied, suggesting that the synthesis of xylan in Saccharum may conserve a core pentasaccharide structure (Xyl5) eventually modified with acetyl and feruloyl substituents.

\section{Authors' details \\ ${ }^{1}$ Universidade Federal de Goiás, Goiânia, Brazil. ${ }^{2}$ Universidade Federal de Viçosa, Viçosa, Brazil.}

Published: 1 October 2014 


\section{References}

1. Cosgrove DJ: Cell wall loosening by expansins. Plant Physiol 1998, 118:333-339.

2. Sorensen HR, Pedersen S, Meyer AS: Characterization of solubilized arabinoxylo- oligossacharides by MALDI-TOF MS analysis to unravel and direct enzyme catalyzed hydrolysis of insoluble wheat arabinoxylan. Enz Microb Technol 2007, 41(1-2):103-110.

3. Wang J, Sporns P, Low NH: Analysis of food oligosaccharides using MALDI-MS: quantification of fructooligosaccharides. J Agric Food Chem 1999, 47(4):1549-1557.

doi:10.1186/1753-6561-8-S4-P104

Cite this article as: Lopes et al: Hemicellulose from cane bagasse as assessed by OLIMP MALDI-TOF/MS. BMC Proceedings 2014 8(Suppl 4): P104.

Submit your next manuscript to BioMed Central and take full advantage of:

- Convenient online submission

- Thorough peer review

- No space constraints or color figure charges

- Immediate publication on acceptance

- Inclusion in PubMed, CAS, Scopus and Google Scholar

- Research which is freely available for redistribution

Submit your manuscript at www.biomedcentral.com/submit
C Biomed Central 